\title{
KORELASI KADAR HIGH SENSITIVITY C-REACTIVE PROTEIN DENGAN KADAR LOW DENSITY LIPOPROTEIN PADA PENYANDANG OBES
}

\author{
Rama Dhanivita Djamin ${ }^{1)}$, Hanifah Maani $^{2}$, Zelly Dia Rofinda ${ }^{2)}$, Efrida $^{2)}$ \\ ${ }^{1}$ PPDS Patologi Klinik FK UNAND/ RSUP Dr. M. Djamil \\ email: ramadhanivitadjamin99@gmail.com \\ ${ }^{2}$ FK UNAND/ RSUP Dr. M. Djamil
}

Submitted : 06-03-2020, Reviewer:13-04-2020, Accepted: 15-05-2020

\begin{abstract}
Obesity occurs because of excess fat accumulation in the body. Fat accumulation causes low grade inflammation in adipose tissue which causes an increase in inflammatory cytokines such as tumor necrosis factor-alpha, interleukin-1 beta, and interleukin-6 (IL-6). Increased IL-6 secretion will stimulate the liver to increase acute phase protein production. High sensitivity $C$-reactive protein (hs$C R P)$ is an acute phase protein as inflammatory marker. Low density lipoprotein (LDL-cholesterol) is lipoprotein that contains highest cholesterol. Elevated of hs-CRP and LDL-cholesterol levels in obesity have been identified as risk factors for atherosclerosis. A cross-sectional analytic study to analyze the correlation between hs-CRP and LDL-cholesterol in obese people, from September 2018 to August 2019. The levels of hs-CRP and LDL-cholesterol were measured by the enzyme linked immunoassay (ELISA) and calculation methods (Friedewald). Data were analyzed using Spearman correlation test. Correlation was significant if $p$ value $<0.05$. Results: The study subjects were 26 obese people consisted of 6 men (23.1\%) and 20 women (76.9\%). The mean age was 36.46(7.68) years, hs-CRP level was 5.08(1.28) $\mathrm{mg} / \mathrm{L}$ and LDL-cholesterol level was 154.69(45.8) $\mathrm{mg} / \mathrm{dL}$. Correlation analysis showed a weak positive correlation between hs-CRP and LDL-cholesterol levels and not statistically significant $(r=0.333, p=0.096)$. Conclusion: There is a weak positive correlation between hs-CRP and LDL-cholesterol levels in obese people.
\end{abstract}

Keywords: Obesity, High Sensitivity C-Reactive, Low Density Lipoprotein

\begin{abstract}
Abstrak
Obesitas terjadi karena akumulasi lemak berlebih di dalam tubuh. Akumulasi lemak menimbulkan low grade inflammation pada jaringan adiposa, menyebabkan peningkatan sitokin inflamasi seperti tumor necrosis factor-alpha, interleukin-1 beta, dan interleukin-6 (IL-6). Peningkatan sekresi IL-6 merangsang hepar meningkatkan produksi protein fase akut. High sensitivity $C$-reactive protein ( $h s-C R P$ ) sebagai penanda inflamasi merupakan protein fase akut. Low density lipoprotein (LDL-kolesterol) adalah lipoprotein yang paling banyak mengandung kolesterol. Peningkatan kadar hs-CRP dan kadar LDL-kolesterol pada obesitas diidentifikasi sebagai faktor risiko aterosklerosis. Penelitian ini bertujuan menganalisis hubungan hs-CRP dengan LDL-kolesterol pada penyandang obes, merupakan penelitian analitik rancangan potong lintang dilakukan September 2018 sampai Agustus 2019. Kadar hs-CRP diperiksa dengan metode enzyme linked immunoassay (ELISA), sedangkan kadar LDL-kolesterol dengan metode kalkulasi (rumus Friedewald). Uji korelasi Spearman digunakan untuk menganalisi data, jika didapatkan nilai $p<0,05$ korelasi dinyatakan bermakna. Subjek penelitian berjumlah 26 penyandang obes terdiri dari 6 lakilaki $(23,1 \%)$ dan 20 perempuan $(76,9 \%)$. Rerata umur subjek penelitian adalah $36,46(7,68)$ tahun. Rerata kadar hs-CRP dan kadar LDL-kolesterol adalah 5,08(1,28) $\mathrm{mg} / \mathrm{L}$ dan 154,69(45,8) $\mathrm{mg} / \mathrm{dL}$. Analisis korelasi menunjukkan korelasi positif lemah dan tidak bermakna secara statistik antara kadar hs-CRP dengan kadar LDL-kolesterol ( $r=0,333, p=0,096)$. Simpulan: Terdapat korelasi positif lemah antara kadar hs-CRP dengan kadar LDL-kolesterol pada penyandang obes.
\end{abstract}

Kata kunci: Obesitas, High Sensitivity C-Reactive, Low Density Lipoprotein 


\section{PENDAHULUAN}

Obesitas merupakan suatu keadaan akumulasi lemak yang berlebihan di jaringan adiposa. Obesitas saat ini disebut dengan The New World Syndrome, angka kejadiannya terus meningkat diseluruh dunia. Sebanyak lebih dari satu milyar orang dewasa dengan berat badan lebih (gemuk) di seluruh dunia dilaporkan dan paling sedikit ada 300 juta orang termasuk obesitas. Faktor genetik dan faktor lingkungan merupakan penyebab sebagian besar obesitas, seperti aktivitas, gaya hidup, sosial ekonomi dan nutrisional (Husna, 2012; Hendra dkk, 2016).

Ketidakseimbangan antara energi yang masuk dengan energi yang keluar dalam jangka waktu yang lama dapat menyebabkan terjadinya obesitas. Energi yang berlebih dari makanan yang dikonsumsi akan setelah digunakan untuk metabolisme dan aktivitas sehari-hari, akan disimpan dalam bentuk lemak dan jaringan lemak sehingga menyebabkan pertambahan berat badan. Asupan energi tinggi dapat diperoleh dari makanan yang mengandung lemak tinggi, kurangnya aktivitas fisik dan sedentary life style menyebabkan pengeluaran energi yang rendah (Rismawanti\&Woro, 2016; Novela 2019).

Cara paling banyak digunakan untuk mengetahui seseorang mengalami obesitas adalah menggunakan indeks massa tubuh (IMT). Indeks massa tubuh merupakan metode pemeriksaan indikator lemak tubuh dan skrining berat badan yang dapat mengakibatkan masalah kesehatan, tidak mahal dan mudah dilakukan. Indeks massa tubuh berkorelasi dengan pengukuran lemak tubuh secara langsung, tetapi tidak mengukur lemak tubuh secara langsung. Indeks massa tubuh menggunakan perhitungan kilogram per meter kuadrat $\left(\mathrm{kg} / \mathrm{m}^{2}\right)$. Indeks massa tubuh $>30 \mathrm{~kg} / \mathrm{m}^{2}$ secara klinik dinyatakan sebagai obesitas, sedangkan untuk orang Asia obesitas apabila IMT $>25 \mathrm{~kg} / \mathrm{m}^{2}$ (Salam, 2010; Manik, 2011).

Obesitas berdampak terhadap faktor risiko kardiovaskuler, kesulitan bernafas, gangguan faal hati, masalah ortopedik berhubungan dengan obesitas, kelainan kulit dan psikiatrik. Kadar low density lipoprotein (LDL) dan kadar high sensitivity $C$-reactive protein (hs-CRP) yang meningkat pada obesitas merupakan faktor risiko terjadinya aterosklerosis (Salam, 2010; Budiono dkk, 2014).

Obesitas terjadi karena akumulasi lemak berlebih di dalam tubuh. Akumulasi lemak menimbulkan low grade inflammation pada jaringan adiposa yang menyebabkan peningkatan sitokin inflamasi seperti tumor necrosis factor-alpha, interleukin-1 beta, dan interleukin-6 (IL-6). Peningkatan sekresi IL6 akan merangsang hepar meningkatkan produksi protein fase akut (Silor, 2011; Faam dkk, 2014; Lavanya dkk, 2017).

Orang dengan obesitas mempunyai kadar trigliserida yang tinggi yang tersimpan dibawah kulit. Trigliserida merupakan bahan utama pembentukan very low density (VLDL) di hati dan sering menyebabkan terjadinya peningkatan kadar kolesterol total, LDL-kolesterol dan VLDL. Peningkatan konsentrasi low-density lipoprotein (LDL) kolesterol merupakan faktor risiko pada penyakit aterosklerosis dan inflamasi berhubungan terhadap perkembangan dan progress aterosklerosis (Elim dkk, 2012; Nisa, 2016).

C-reactive protein merupakan molekul polipeptida dari kelompok pentraxins yang merupakan protein fase akut sebagai penanda inflamasi. High sensitivity $C$-reactive protein (hs-CRP) merupakan molekul yang sama dengan $C$-reactive protein (CRP). Perbedaan antara CRP dan hs-CRP adalah pada sensitivitas analitiknya dimana hs-CRP dapat mengukur kadar CRP yang sangat rendah (Dewi, 2018).

Pengukuran kadar CRP menggunakan immunoassays dengan teknik immunoturbidimetric dan nephelometric. Batas terendah deteksi teknik ini antara 3 sampai $5 \mathrm{mg} / \mathrm{L}$. Teknik pengukuran CRP yang lebih sensitif dikembangkan menggunakan ultrasensitive ELISA atau particle-enhanced techniques dan diberi nama "high sensitivity" atau "highly sensitive" CRP pada pertengahan 1990an. Batas deteksi teknik ini adalah $0,3 \mathrm{mg} / \mathrm{L}$, dapat disimpulkan hs-CRP dapat mengukur kadar CRP yang rendah pada orang sehat (CCL, 2012; DBC, 2018). 
Low Density Lipoprotein (LDL) merupakan lipoprotein yang paling banyak mengandung kolesterol, yang berperan dalam pengangkutan fraksi lemak, terutama kolesterol dari hati menuju ke sel perifer. Low Density Lipoprotein memiliki inti hidrofobik dan mengandung kolesterol ester paling banyak dibandingkan lipoprotein lain (35-40\%) (Noviyanti, 2011; Shania dkk, 2015).

Beberapa penelitian meneliti tentang korelasi kadar high sensitivity $C$-reactive protein dengan kadar low density lipoprotein pada obesitas. Penelitian oleh Budiono et al., (2014) mendapatkan terdapat hubungan positif $(r=0,544, p=0,024)$ yang signifikan antara keduanya pada remaja obes. Penelitian tahun 2001 oleh Nishide et al., pada anak usia sekolah (6-11 tahun) di Jepang mendapatkan hal yang sama yaitu kadar low density lipoprotein memiliki korelasi positif $(\mathrm{r}=0,200, \mathrm{p}=0.082)$ dengan kadar high sensitivity c-reactive protein pada anak obes. Penelitian lain oleh Faam et al., (2014) juga mendapatkan korelasi positif $(\mathrm{r}=0,156, \mathrm{p}=$ 0,029) antara kadar high sensitivity $c$ reactive protein dengan kadar low density lipoprotein pada dewasa obes di Tehranian.

\section{METODE PENELITIAN}

Penelitian ini merupakan penelitian analitik rancangan potong lintang, yang dilakukan dari bulan September 2018 sampai Agustus 2019. Populasi adalah pekerja laboratorium sentral RSUP Dr. M. Djamil Padang. Sampel dalam penelitian ini berjumlah 26 orang. Kadar hs-CRP diperiksa dengan metode enzyme linked immunoassay (ELISA), sedangkan kadar LDL-kolesterol diperiksa dengan metode kalkulasi (rumus Friedewald). Data dianalisis menggunakan Uji korelasi Spearman digunakan untuk menganalisi data dan dinyatakan bermakna jika didapatkan nilai $\mathrm{p}<0,05$.

\section{HASIL DAN PEMBAHASAN}

Penelitian dilakukan terhadap 26 orang pekerja obesitas yang memenuhi kriteria inklusi dan eksklusi.
Tabel 1.1 Karakteristik Subjek Penelitian

\begin{tabular}{lll}
\hline Variabel & $\mathbf{f}(\%)$ & Rerata (SD) \\
\hline Jenis Kelamin & & \\
Laki-laki & $6(23,1)$ & \\
Perempuan & $20(76,9)$ & \\
Umur (tahun) & & $33,2(6,8)$ \\
\hline
\end{tabular}

Subjek penelitian terdiri dari 6 orang laki-laki $(23,1 \%)$ dan 20 orang perempuan $(76,9 \%)$. Rerata umur subjek penelitian adalah 36,46(7,68) tahun dengan rentang umur 25-57 tahun.

Tabel 1.2 Kadar High Sensitivity C-Reactive Protein

\begin{tabular}{ll}
\hline Variabel & Rerata $(\mathrm{SD})$ \\
\hline Hs-CRP & $5,08(1,28)$ \\
\hline
\end{tabular}

Pemeriksaan kadar hs-CRP subjek penelitian dilakukan dengan metode ELISA dan didapatkan rerata dan median 5,08 $(1,28)$ dengan kadar terendah 3,07 mg/L dan kadar tertinggi 7,39 $\mathrm{mg} / \mathrm{L}$.

Tabel 1.3 Kadar Low Density Lipoprotein

\begin{tabular}{ll}
\hline Variabel & Rerata (SD) \\
\hline LDL-kolesterol & $154,69(45,8)$ \\
\hline
\end{tabular}

Pemeriksaan kadar LDL-kolesterol subjek penelitian dilakukan dengan metode kalkulasi dan didapatkan rerata dan median 154,69(45,8) dengan kadar terendah 121 $\mathrm{mg} / \mathrm{dL}$ dan kadar tertinggi $353 \mathrm{mg} / \mathrm{dL}$.

Uji normalitas menggunakan Shapiro-Wilk dilakukan terhadap kadar hsCRP dan kadar LDL-kolesterol. Uji ini mendapatkan hasil data terdistribusi normal pada kadar hs-CRP dan hasil data tidak terdistribusi normal pada kadar LDLkolesterol. Transformasi log dilakukan untuk kadar LDL-kolesterol. Uji korelasi Spearman dilakukan antara kadar hs-CRP dengan kadar LDL-kolesterol, setelah transformasi log hasil data kadar LDL-kolesterol tidak terdistribusi normal. 


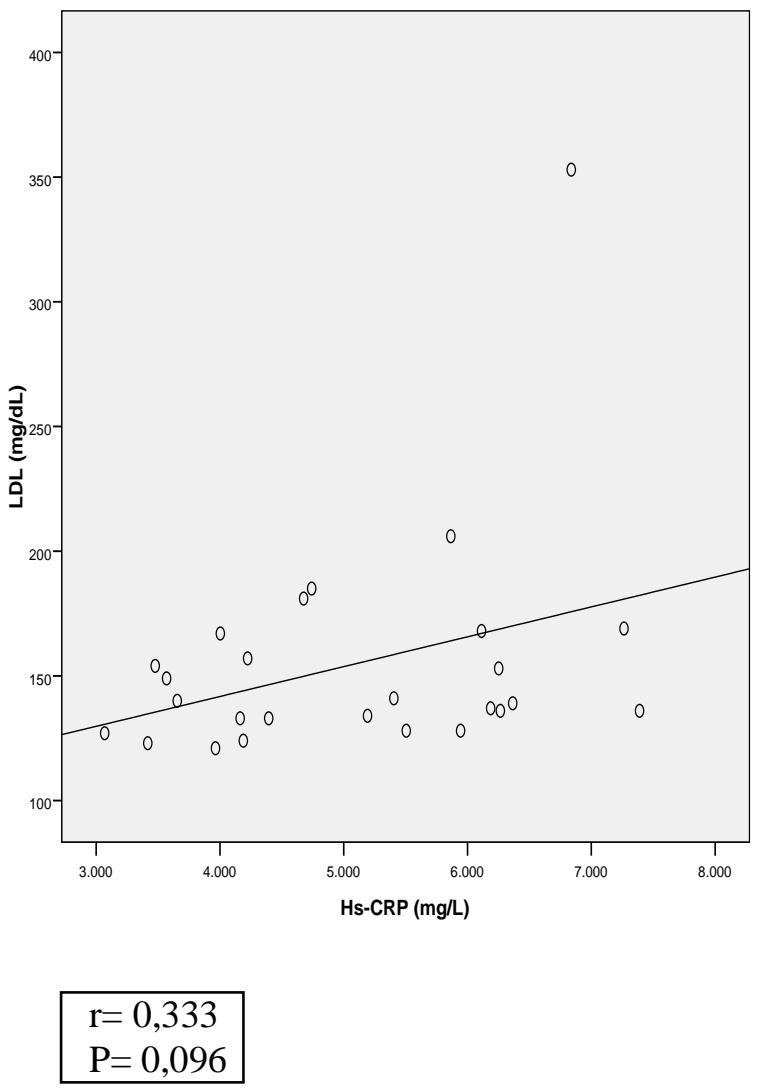

Gambar 1 Korelasi Kadar High Sensitivity $C$ Reactive Protein Dengan Kadar Low Density Lipoprotein

Subjek penelitian berjumlah 26 orang penyandang obes dengan jenis kelamin perempuan $(76,9 \%)$ lebih banyak dibanding laki-laki $(23,1 \%)$. Hasil ini tidak sesuai dengan penelitian yang dilakukan oleh Budiono et al., (2014), dimana jumlah jenis kelamin laki-laki $(64,7 \%)$ lebih banyak daripada perempuan (35,3\%). Penelitian Nishide et al., (2001) juga mendapatkan jumlah anak laki-laki yang obes $(86,8 \%)$ lebih banyak dari perempuan.

Rerata umur penyandang obesitas pada penelitian ini $36,46(7,68)$ tahun dengan rentang umur 25-57 tahun. Beberapa faktor berperan terhadap terjadinya perubahan keseimbangan energi yang dapat mengakibatkan obesitas seperti konsumsi makanan cepat saji (fast food) yang berlebihan, aktivitas fisik yang rendah, genetik, psikologis, status sosial ekonomi, program diet, usia, dan jenis kelamin (Kurdanti et al., 2015). Penelitian Sugiarti L\&Latifah (2011) mendapatkan tidak ada korelasi umur dan jenis kelamin terhadap obesitas.
Rerata kadar hs-CRP pada subjek penelitian adalah 5,08 (1,28) dengan kadar terendah 3,07 mg/L dan kadar tertinggi 7,39 mg/L. Penelitian Faam et al., (2014) mendapatkan peningkatan kadar hs-CRP pada obesitas. Penelitian Budiono et al., (2014) juga mendapatkan peningkatan kadar hs-CRP tidak signifikan 1,30(1,46).

Jaringan adiposa mensekresikan sitokin pro-inflamasi seperti TNF- $\alpha$, IL- $1 \beta$, dan IL-6. Peningkatan sekresi sitokin oleh penderita obesitas menimbulkan inflamasi yang ditandai dengan tingginya kadar kosentrasi IL-6 di dalam plasma sebanding terhadap massa lemak. Peningkatan sekresi IL-6 akan merangsang hepar meningkatkan produksi protein fase akut (CRP) (Faam dkk, 2014; Lavanya dkk, 2017).

Rerata kadar LDL-kolesterol pada subjek penelitian ini adalah 154,69(45,8) dengan kadar terendah $121 \mathrm{mg} / \mathrm{dL}$ dan kadar tertinggi $353 \mathrm{mg} / \mathrm{dL}$. Penelitian ini sama dengan penelitian Budiono et al., (2014) mendapatkan kadar LDL-kolesterol pada obes 122(28,46). Hastuty (2018) mendapatkan tidak terdapat perbedaan bermakna kadar kolesterol pada kelompok obes dan non obes 190,11(52,73).

Akumulasi lemak pada obesitas menyebabkan kelebihan lemak pada jaringan adiposa. Orang dengan obesitas memiliki kadar trigliserida yang tinggi yang terdapat dibawah kulit. Trigliserida merupakan bahan utama pembentukan very low density (VLDL) di hati, yang dapay menyebabkan terjadinya peningkatan kadar kolesterol total, dan LDL-kolesterol dan VLDL (Elim dkk, 2012; Nisa, 2016).

Penelitian ini mendapatkan hasil korelasi positif lemah antara kadar hs-CRP dengan LDL-kolesterol $(\mathrm{r}=0,333)$ secara statistik tidak bermakna $(\mathrm{p}<0,05)$ Hasil penelitian ini sesuai dengan penelitian yang mendapatkan korelasi yang positif antara kadar hs-CRP dengan kadar LDL-kolesterol. Beberapa penelitian Ronaldo (2018) dan Suhartini (2018) mendapatkan tidak adanya korelasi antara kadar hs-CRP dengan kadar LDL-kolesterol.

Perbedaan hasil dengan Ronaldo (2018) dan Suhartini (2018) kemungkinan dipengaruhi oleh metode penelitian yang 
berbeda yaitu penelitian ini meneliti pada anak dengan sindroma nefrotik dan pada pasien hipertensi non obes. Berdasarkan kepustakaan, obesitas dapat meningkatkan kadar hs-CRP dan kadar LDL-kolesterol. Kondisi low grade inflammation terjadi pada obesitas terutama pada jaringan adiposa yang menyebabkan peningkatan sitokin inflamasi, seperti TNF- $\alpha$, interleukin- 6 , monocyte chemotactic protein 1, transforming growth factor $\beta 1$, dan faktor-faktor prokoagulan. Peningkatan sekresi IL-6 merangsang hepar meningkatkan produksi protein fase akut, sesuai dengan hasil penelitian ini.

Beberapa kepustakaan menyatakan bahwa kadar hs-CRP dalam tubuh dapat dipengaruhi faktor lain, selain disebabkan oleh obesitas, kadar hs-CRP dapat dipengaruhi kondisi fisik dan kebiasaan hidup seperti aktivitas fisik, merokok dan konsumsi alkohol, namun tidak dipengaruhi oleh usia dan etnik (Suhartini, 2018).

Obesitas merupakan suatu keadaan yang terjadi dikarenakan jumlah asupan energi lebih besar daripada jumlah energi yang digunakan oleh tubuh. Kelebihan energi berupa zat nutrisi dari makanan, seperti lemak, karbohidrat, dan protein akan disimpan sebagai lemak di jaringan adiposa. Enzim lipoprotein lipase banyak terdapat pada hati dan jaringan adiposa, yang terdapat pada endotel kapiler akan menghidrolisis triasilgliserol pada VLDL membentuk IDLkolesterol yang juga akan di hidrolisis oleh enzim lipoprotein lipase menjadi LDLkolesterol (Budiono dkk, 2014; Hastuty, 2018).

\section{SIMPULAN}

Terdapat korelasi positif lemah antara kadar hs-CRP dengan kadar LDL-kolesterol pada penyandang obes dan tidak bermakna secara statistik $(\mathrm{r}=0,333, \mathrm{p}=0,096)$, sehingga dapat disimpulkan bahwa pada penyandang obes terjadi peningkatan kadar hs-CRP dan kadar LDL-kolesterol.

\section{UCAPAN TERIMAKASIH}

Terima kasih kepada semua pihak yang telah membantu dalam pelaksanaan penelitian ini dan rumah sakit M. Djamil Padang.

\section{REFERENSI}

Budiono D, Kalisis SHM, Assa YA. 2014. Hubungan Kadar Kolesterol Low Density Lipoprotein Plasma dengan Kadar High Sensitivity C-Reactive Protein Pada Remaja Obes. Journal Ebiomedik, Vol. 2, No.1.

Cleveland Clinic Laboratories. 2012. High Sensitivity C-Reactive Protein (hsCRP). Cleveland Clinic Ohio.

Dewi YP. C-reactive Protein (CRP) VS High-sensitivity CRP (hs-CRP). 2018. diunduh dari https://www.researchgate.net/publicati on/327690708, tanggal 2 Agustus 2019.

Diagnostics Biochem Canada. 2018. High Sensitivity C-Reactive Protein (hsCRP) ELISA, Ref: CAN CRP-4360, p:1-2.

Elim C, Pangemana DHC, Supit S, Lindo V, Warouw SM. 2012. Gambaran Kadar Low Density Lipoprotein (LDL) Pada Siswa-siswi Overweight Dan Obesitas Di Kota Manado. Jurnal Biomedik, Vol. 4, No.3 suppl S:69-76.

Faam B, Zarkesh M, Daneshpour MS, Azizi F, Hedayati H. 2014. The Association Between Inflammatory markers And Obesity Related Factors In Tehranian adults: Tehran Lipid And Glucose Study. Iranian Journal Of Basic Medical Sciences.

Hastuty YD. 2018. Perbedaan Kadar Kolesterol Orang Yang Obesitas Dengan Orang Yang Non Obesitas. Jurnal Kedokteran dan Kesehatan Malikussaleh.

Hendra C, Manampiring A.E, Budiarso F. 2016. Faktor-faktor Risiko Terhadap Obesitas Pada Remaja Di Kota Bitung. Jurnal e-Biomedik (eBm), Vol.4, No.1.

Husna. 2012. Tata Laksana Obesitas. Jurnal Kedokteran Syiah Kuala, Vol.12, No. 2.

Lavanya K, Ramamoorthf K, Acharya RV, Madhyastha SP. 2017. Association between Overnight, Obesity In Relation To Serum hs-CRP Levels In Adults 20-70 Years. Journal of Clinical and Research, Vol.11, No.12. 
Manik CPN. 2011. Hubungan Jumlah Jam Tidur Dengan Indeks Massa Tubuh Pada Mahasiswa Fakultas Kedokteran Universitas Sumatera Utara ; diunduh dari

http://repository.usu.ac.id/handle/1234 56789/32514, tanggal 19 Agustus 2019 .

Nisa H. 2016. Peran C-reactive Protein Untuk Menimbulkan Risiko Penyakit, Vol.13, No.1.

Novela V. 2019. Hubungan Konsumsi Zat Gizi Mikro Dan Pola Makan Dengan Kejadian Obsitas. Jurnal Human Care, Vol.4, No.3(October, 2019):190-198.

Noviyanti F, Decroli E, Sastri S. 2015. Perbedaan Kadar LDL-kolesterol Pada Pasien Diabetes Mellitus Tipe 2 Dengan Dan Tanpa Hipertensi Di RS Dr. M. Djamil Padang Tahun 2011. Jurnal Kesehatan Andalas, 4(2).

Rismawanti I dan Woro OKH. Media Buletin Dan Seni Mural Dalam Upaya Meningkatkan Pengetahuan Tentang Obesitas. 2016. Journal Of Public Health Universitas Negeri Semarang, $1(1)$.

Salam A. 2010. Faktor Risiko Kejadian Obesitas Pada Remaja. Jurnal MKM, Vol.6, No.3:185-190.

Sanhia AM, Panemanan DHC, Engka JNA. 2015. Gambaran Kadar Kolesterol Low Density Lipoprotein (LDL) Pada Masyarakat Perokok Di Pesisir Pantai. Jurnal e-Biomedik, Vol.3, No.1.

Silor PF. 2011. Korelasi Body Mass Index (BMI) Dan Triceps Skinfold Thickness Terhadap Kadar hs-CRP Dalam Darah. Fakultas Farmasi Universitas Sanata Dharma Yogyakarta.

Suhartini. 2018. Korelasi High Sensitivity CReactive Protein (hs-CRP) dan Kolesterol Low Desinty Lipoprotein (LDL) Pada Pasien Hipertensi Non Obes. Universitas hasanuddin Makassar. 